\title{
REGIONAL REQUIREMENTS OF THE MEDICAL EDUCATION, MEDICAL ADULT EDUCATION'S PRESENT AND FUTURE IN THE NORTH VOJVODINA REGION
}

\section{REGIONÁLIS IGÉNYEKET SZOLGÁLÓ EGÉSZSÉGÜGYI SZAKOKTATÁS, FELNŐTTKÉPZÉS JELENE, JÖVŐJE AZ ÉSZAK- VAJDASÁGI RÉGIÓBAN}

\author{
Zoltán Takács, okl. közgazdász \\ Pécsi Regionális Politika és Gazdaságtan Doktori Iskola, \\ Regionális Tudományi Társaság Szabadka. \\ Cím: $\quad 24420$ Magyarkanizsa, Sumádia utca 31. \\ Tel: $\quad$ 063-16-19-118 \\ 062-27-28-45 \\ E-mail: $\quad$ takacszoli@stcable.rs
}




\title{
REGIONAL REQUIREMENTS OF THE MEDICAL EDUCATION, MEDICAL ADULT EDUCATION'S PRESENT AND FUTURE IN THE NORTH VOJVODINA REGION
}

\section{REGIONÁLIS IGÉNYEKET SZOLGÁLÓ EGÉSZSÉGÜGYI SZAKOKTATÁS, FELNŐTTKÉPZÉS JELENE, JÖVŐJE AZ ÉSZAK- VAJDASÁGI RÉGIÓBAN}

\author{
Abstract \\ Keywords: medical branch in contrast to medical education, adult education's network, needs of new \\ competence, regional empirical results
}

The medical branch and institutional infrastructure as well as medical education have to face the inherited deficiencis of the previous system. Due to the fact that regionalization programs support headcount reduction, the newly graduates and former students are often searching for years to find themselves a job. This is a proof that there isn't any convergence between the existing educational system and the labor market. Our educational system does not track the changes that are taking place on the market, nor the necessary competences suggested by the employers. The North Voivodina region the medical high schools (in Senta, Subotica) and employers (medical and social service providers, medical institutions and private practices) should mutually develop an educational network. This way they could relieve the labor organizations representing the unemployed. A competent workforce is of high importance for the employers. However it can be provided only by the schools with the latest educational programs which are adapting to the changing needs of the marketplace.

\section{Kivonat}

Kulcsszavak: egészségügy - egészségügyi oktatás, felnőttképzési háló, kompetencia-igény, regionális empirikus kutatási eredmények

\begin{abstract}
Az „örökölt rendszer” hiányosságaival szembesül, mint az oktatás, mint az egészségügy ágazati-intézményi infrastruktúrája. A racionalizációs programok a létszám mind radikálisabb leépítését szorgalmazzák, így az iskolapadokból kikerülő friss diplomások, érettségizők sokszor csak évek múltán tudnak munkába állni. Ez a tény egyértelmüen alátámasztja az oktatási rendszer és a munkaerő-piac közötti nem létező konvergenciát. Oktatási rendszerünk, nem követi a piaci változásokat, nem követi a munkáltatók által sugallt kompetenciákra épülő képzést. Az Észak-vajdasági régióban, az egészségügyi oktatást folytató középiskolák (Zenta, Szabadka), karöltve a munkáltatókkal (egészségügyi-és szociális szolgáltatást folytató egészségügyi intézmények, magánpraxisok) kell, hogy hozzájáruljanak egy közös képzési háló kidolgozásához, amellyel tehermentesíteni tudják a munkanélkülieket képviselő munkaügyi hivatalokat jövőbeli feladataik végzésében. A munkáltatók számára a kompetens munkaerő a legfontosabb, amelyet csak a piaci igényekhez rugalmasan alkalmazkodó oktatási/képzési programokat képviselő iskolák fogják tudni biztosítani.
\end{abstract}




\section{BEVEZETŐ}

A Szabadkai Regionális Tudományi Társaság 2008-ban kutatást kezdeményezett az észak-Bácskai iskolahálózat felnöttképzési kapacitásainak feltérképezése céljából. A kutatás ágazatokra bontva történt, így külön az egészségügy és szociális védelem területén. Az empirikus kutatás kiterjedt a régió munkáltatóira (állami egészségügyi intézményekre, magánpraxisokra), a szakközépiskolákra, valamint a foglalkoztatás-ügyi hivatalokra. Az érintett felek megszólaltatása, érdekeik, véleményeik összegzése, ütköztetése révén került sor a régió felnöttképzési sajátosságainak, problémáinak megfogalmazására. Jelen tanulmány ezen projekt egészségügyi témakörben végzett kutatásának eredményeiröl számol be, röviden. ${ }^{2}$ A kutatási projektet a Szülőföld Alap, a Magyar Tudományos Akadémia Magyar Tudományosság Külföldön Elnöki Bizottsága, az MTA Etnikai-nemzeti Kisebbségkutató Intézete és a Tartományi Oktatási és Müvelödési Titkárság támogatta. A Képzetteké a jövö c. kötet gondozását a Szabadkai Regionális Tudományi Társaság vállalta magára.

\section{KUTATÁSI PROBLÉMA, MÓDSZERTAN, CÉL ÉS HIPOTÉZIS}

A kutatási probléma: A szerb oktatási rendszer hiányosságaiból fakadóan a felnőttképzés, felnőttoktatás rendszere a mai napig nem tudott intézményesülni. Ennek hiányát gazdasági áganként elemezhetjük, ugyanis a munkaerő-piaci kompetenciák, versenyképes tudás átörökítése marad el ezáltal. A munkaadók igényei azonban relevánsak, sajnos azonban a rendszerbeli hiányosságok miatt nem találkozik a munkaerőpiac által képviselt szakmakínálat az általuk megfogalmazott szakmakereslettel, kompetenciaigényekkel.

Kutatási cél: megvizsgálni a régió oktatási intézményeinek tevékenységét, oktatási kínálatát, megvizsgálni a munkáltatók által képviselt - a munkavállalóval szembeállított elvárásokat, és elemezni a foglalkoztatás ügyi hivatalok nyilvántartását, az egyes oktatási profilokat képviselők számát. Majd, véleményezés és megoldási javaslatok megfogalmazása, stratégiai döntés-előkészítés a helyi-regionális elit számára.

\footnotetext{
2 A tanulmány tartalma előadásként hangzott el a „Határtalan határok” Tudományos Földrajzi Konferencián, Dobogókőn, 2008. október 26-27-én, a Magyar Regionális Tudományi Társaság VI. Vándorgyülésén, Gödöllőn 2008. december 11-12-én, illetve a Szabadkai Értelmiségi Kerekasztalon, 2009. április 1-én.
} 
A kutatás módszertana:

1. primer adatgyüjtés:

- esettanulmányok kidolgozása az egészségügyi szakképzéssel foglalkozó középiskolákról,

- mélyinterjúk készítése és elemzése a munkaadói oldalról (cégvezetők, magánvállalkozók),

2. Statisztikai elemzések az ágazati humánerőforrás képzettségét illetően, kiemelve területi sajátosságaikat.

A kutatás hipotézisei:

- Általános jellegü a passzivitás a felsőbb központi hatalmi szervek által behatárolt mozgástérben, oktatásban, egészségügyben, foglalkoztatás ügyben egyaránt.

- A munkáltatói elvárások felülmúlják az oktatási intézményi-infrastruktúra által szavatolt kompetenciákat.

- Ad hoc müködő felnőttoktatási rendszerrel rendelkezik a régió. Nem történik érdekegyeztetés, párbeszéd indítványozása a következő reláción: oktatási intézmények - egészségügyi intézmények - foglalkoztatás ügyi hivatalok.

\section{AZ EGÉSZSÉGÜGY NÉHÁNY NEMZETI ÉS NEMZETKÖZI HUMÁN VONATKOZÁSA}

Az egészségügyi rendszer reformjai Szerbiában 2001-ben kezdődtek meg. A folyamat intenzívebbé 2005-től válik, az ágazati törvénycsomag elfogadásával. A 2001-től 2004-ig tartó időszakra jellemző a reformfolyamatok előkészítése, az egészségügyi politika víziójának megfogalmazása, stratégiai alapelvek összegzése, a reformokat lefolytató szakértői csoportok kinevezése. A reformok befejezésének várható időpontja 2015. A kormány által képviselt álláspont szerint „a nép egészségügyi állapota közösségi érdek, az egészség pedig a legfontosabb fejlödési erőforrás“ (MzRS. 2003). A nemzeti egészségpolitika konzisztens célrendszerében prioritást képez az egészségügy humánerőforrás bázisának fejlesztése. Az egészségvédelem minőségi feltételeinek biztosításához, minőséges szolgáltatásnyújtáshoz nélkülözhetetlen a minőséges emberi erőforrás. A minőség folyamatos megtartása pedig az oktatás, illetve képzési programok 
által szavatolt szellemi kondíciómegtartással, szakmai felkészültséggel, ismeretgyarapítással valósulhat csak meg.

Szerbiában három évtized alatt az egészségügyi munkások száma 130\%-kal növekedett meg. Ezzel szemben a kórházi kapacitások 21\%-kal bővültek, míg a lakosság száma mindössze 15\%-kal növekedett meg. Változás történt az egészségügyi munkások képzettségi struktúrájában is: csökkent a nem egészségügyi munkások és az alacsonyabb végzettségü egészségügyi munkások részaránya, emellett pedig rendkívül megnőtt a felsőfokú végzettséggel rendelkező egészségügyi munkások száma. Ezzel a teljes szerbiai egészségvédelem „,szakorvosi” szintre emelkedett: az orvostársadalom 72,6\%-a szakorvos, 10,3\%-a szakosodott szakorvos, így valójában általános orvos az orvostársadalom mindössze 17,1\%-a. Fontos továbbá kiemelni az általános szakorvosok -háziorvosok ${ }^{3}$ alacsony arányát a szakorvosokon belül: 11,6\% (MzRS. 2001). A fejlett európai országok gyakorlata, a humánerőforrás ezen területén, mást mutat: a háziorvos/családorvos koncepció térhódítása miatt épp ez az ágazat a legfejlettebb, Finnországban a szakorvosok 1/5-e, Dániában több mint 1/3-a ezen a szakterületen szerzett szakosodást, és tevékenykedik (MzRS. 2003). Szerbia egészségügyének humánellátottsága viszonylag jónak mondható, főleg a Közép-Kelet Európai országok viszonylatában, viszont az Európai Uniótól elmarad.

\begin{tabular}{cccc}
\hline $\begin{array}{c}\text { A lakosság } \\
\text { ellátottsága }\end{array}$ & $\begin{array}{c}\text { Szerb } \\
\text { Köztársaság }\end{array}$ & $\begin{array}{c}\text { Európai Unió } \\
2000\end{array}$ & $\begin{array}{c}\text { Közép-Kelet } \\
\text { Európa 2001 }\end{array}$ \\
\hline $\begin{array}{c}100.000 \\
\text { lakosra jutó }\end{array}$ & 265 & 387 & 244 \\
$\begin{array}{c}100.000 \text { lakóra } \\
\text { jutó háziorvos } \\
100.000\end{array}$ & 42 & 102 & 70 \\
$\begin{array}{c}\text { lakosra jutó } \\
100.000\end{array}$ & 773 & - & 514 \\
$\begin{array}{c}\text { lakosra jutó } \\
100.000\end{array}$ & 45 & 71 & 40 \\
lakosra jutó & 24 & 76 & 35 \\
\hline
\end{tabular}

1. ábra: Emberi erőforrás-ellátottság az egészségügyben, Európában Forrás: Ministarstvo Zdravlja Republike Srbije, 2003.

\footnotetext{
${ }^{3}$ Lekar specijalista opšte medicine
} 


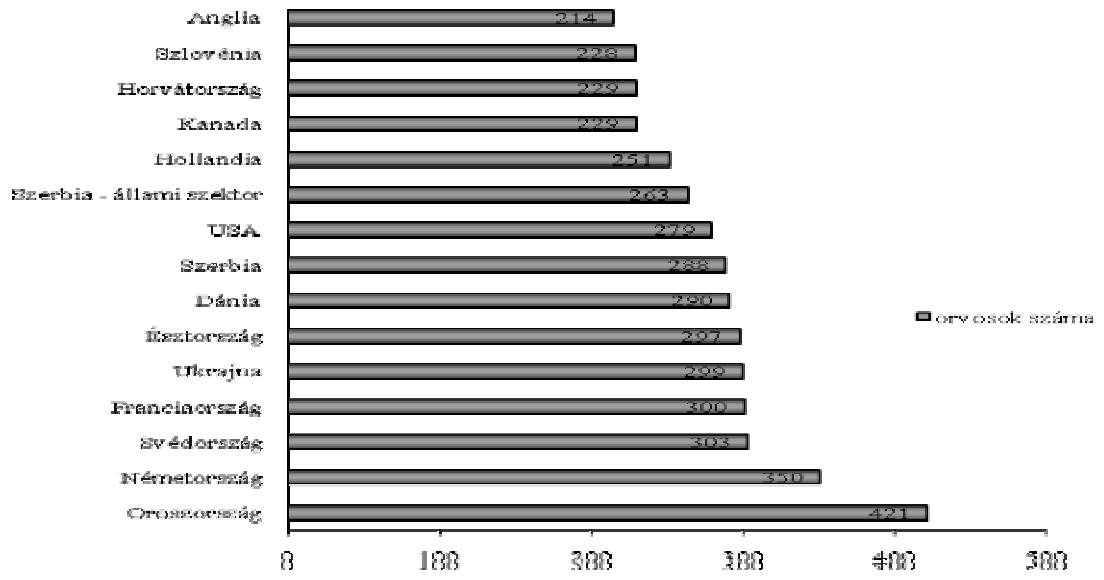

2. ábra: 100.000 före jutó orvosok száma Európa országaiban, 2002-ben Forrás: MILOSAVLJEVIĆ, T. 2005.

Kincses megítélése szerint az egészségügyi rendszer a lakosság „életesélyegyenlöségét meghatározó humán közszolgáltatás, amely nemcsak a lakosság egészségi állapota és biztonságtudata szempontjából kiemelkedö jelentöségü, de az ágazat a fejlett országokban a gazdaság innovatív húzóágazata, melynek foglalkoztatáspolitikai hatása is jelentős"(KINCSES. 2000). A továbbiakban kiemeli még, hogy egy olyan piacról van szó az egészségügy esetében, amely folyamatosan és fokozottan bővül, növekszik az egészségügyi fogyasztás, párhuzamosan pedig az egészségügyi szolgáltatások, illetve a gyógyszeripar, orvosimüszer-ipar. A humán-közszolgáltatások és azok köré csoportosuló ipar által képviselt értékképzési folyamatok minden régió számára pozitív jövőképet kell, hogy jelentsenek. A megfelelő humántőkével rendelkező térségek képesek olyan, nem konvencionális feladatok ellátására is, mint amilyen az egészségturizmus, gyógyfürdőturizmus, luxus-egészségügyiszolgáltatások, kozmetikai szolgáltatások, stb. Ezek további kapacitáskihasználásra, jövedelemtermelésre adnak lehetőséget.

Az egészségügy müködésének kulcsát az ágazatban dolgozó emberek jelentik. Az emberi erőforrás biztosítása és stratégiai menedzsmentje létfontosságú. Az ágazatban zajló radikális átalakítások idején az egészségügyi emberi erőforrás helyzetének áttekintése, elemzése, illetve az egészségügyi szakemberképzés kiemelt szerepet kap. Az humánerőforrás politika legfontosabb célja az egészségügyben: a változó szakmai környezethez igazodó szakemberek biztosítása. Ez különös gondot jelent, hiszen egyrészt a „gyógyítás a technológiai fejlödés ellenére tudás-intenzív, az emberi tudásra alapozott tevékenység, másrészt a gyógyítás azon kevés tevékenységek közé tartozik, ahol a „humáneröforrás” kifejezést szó szerint kell venni: az ellátás humánuma, emberiessége a megfelelö 
szakszemélyzet feltétele (OEP. 2009)." Szerbiában, mind szakmai, mind morális felkészültségbeli hiányosságok is nehezítik a humánerőforrás politika céljainak megvalósítását. A régióban müködő, egészségügyi területen tevékenykedő munkáltatók humánerőforrással kapcsolatos - empirikus kutatás során kifejtett álláspontját összegzi a következő fejezet.

\section{EMPIRIKUS KUTATÁSI EREDMÉNYEK ÉS STATISZTIKAI ELEMZÉSEK}

\section{Munkáltatói oldal által képviselt vélemények, regionális humánerőforrás sajátosságok az egészségügyben}

Az empirikus kutatás során megszólaltatott munkáltatói oldal információkkal szolgált az érintett cégek, gazdasági szubjektumok, intézmények munkaerő-piaci jellemzőiről, munkaerő-piaci stratégiájukról, majd az oktatási intézményekkel kialakított kapcsolataikról. A régióban nyújtandó egészségügyi szolgáltatás (járóbeteg-ellátás, kórházi ellátás, szociális gondoskodás, gyógyszerforgalmazás) állami és magántulajdonú intézményekben, a Köztárasági Egészségbiztosítási Intézet (Republički Zavod za Zdravstveno Osiguranje - RZZO) égisze alatt zajlik. Kiterjed a kommerciális jellegü, kiskereskedelmi áruforgalmazásra is gyógyszertárak esetében, illetve a magántulajdonú egészségügyi szolgáltatás nyújtására is (poliklinikák, magánpraxisok, rendelők, diagnosztikai központok, stb.). További egészségügyi jellegü tevékenységet folytató intézmények között említhetők: a szociális gondoskodást, gerontológiai gondozást, betegápolást, rehabilitációt, testi- és szellemi korlátokkal élők gondozását végző intézmények.

Ezekre az intézményekre a 2005-ös reformok/leépítések/átszervezések miatt változások várnak. Állami szinten gyakoriak lesznek a státuszbeli változások, emellett pedig várható a magánszektor határozottabb expanziója. Ennek értelmében pedig változások várnak az intézményekben dolgozó humánerőforrásra is. Munkaerő-feleslegek jelennek meg, magasabb kompetencia-igényekkel szembesülnek a munkáltatók, foglalkoztatottak egyaránt.

Az Egészségvédelemről szóló törvény 165. szakasza két elkülönülő csoportra osztja az egészségügyi területeken tevékenykedő humán eröforrást:

- Egészségügyi munkások azok a személyek, akik orvosi, fogászati- és gyógyszerészeti egyetemi végzettségüek, illetve más egészségügyi végzettséggel rendelkeznek, és közvetlenül, hivatásként művelik a szakmát, és alkalmazottai egészségügyi intézményeknek, magánpraxisoknak. (...). 
- Egészségügyi munkatársak, középiskolai, főiskolai, illetve egyetemi végzettséggel, akik az egészségvédelem területén meghatározott tevékenységet folytatnak az egészségügyi intézményekben, magánpraxisban.

Az Egészségvédelemről szóló törvény rendelkezik az egészségügyi munkások és egészségügyi munkatársak szakmai továbbképzéséröl, szakmai fejlődéséröl. A munkatárs tudásának, szakmai tapasztalatának bővítése kötelezően kiterjed: specializációra, szűkebb szakosodásra és a folyamatos képzésre (kontinuirana edukacija).

Az egészségügyi munkások, és szakmunkatársak állandó szakmai felkészültségének követését Az Egészségügyi Munkások Kamarája (Komora Zdravstvenih Radnika) végzi, az önálló munkavégzést tanúsító bizonylat/licenc kiadásával, felújításával illetve megvonásával. A Kamara igazgatója által kiadott végzés/licenc az egészségügyi munkást 7 éves időszakra jogosítja fel a munkája végzésére. A licenc felújításához szükségesek azok a folyamatos továbbképzéseken való részvételt tanúsító bizonylatok, amelyeket az akkreditált programok alapján oktatást folytató intézmények adnak ki.

A továbbképzések finanszírozása a törvény értelmében a munkáltató kötelessége (181. szakasz 2. bekezdés). Az egészségügyi intézmények szerepe így a humánerőforrás képzésében/fejlődésében meghatározó. A pénzelés ún. „költségvetési transzferek” formájában történik. Ugyanakkor kifejezetten csak továbbképzésre szóló céleszközt nem utal a Köztársasági Betegbiztosítási Intézet (esetektől függően ezt az intézmények az „Egyéb indirekt költségek” terhére finanszírozzák, amennyiben ki tudják gazdálkodni). Az egészségvédelmi törvény értelmében a Köztársasági Egészségbiztosítási Intézet ezt a munkáltató kötelezettségeként kezeli. Ebben a kettős szorításban az egészségügyi intézményeknek saját (egyéb) eszközökből kell biztosítaniuk a szakemberképzést. Az empirikus kutatás eredményei azt bizonyítják, hogy az intézmények humánerőforrás képzésre, a humánkapacitások kondíciómegtartását, fejlesztését elöirányozó programokra az összforgalmuk kevesebb, mint 1\%-át fordítják.

\section{A humánerőforrás területi sajátosságai}

\section{Munkaerő-hiány, álláskínálatok, munkáltatói követelmények}

Szerbiában 2006. december 31-én, az állami egészségügyi intézményekben dolgozók száma 108975 volt, míg a Vajdaságban 26780 állami alkalmazott dolgozott az 
egészségügyben. Az egészségügyi - ágazati tevékenységre alapjában véve jellemző a magasabb végzettségi szint, magasabb intellektuális kapacitás. A foglalkoztatottak több mint 2/3 közép és felsőfokú végzettséggel rendelkezik. Igen magas a felsőfokú végzettségüek részaránya (20-30\%), míg a középkáderek aránya a legdominánsabb (50\% fölött). A szakképzett- és szakképzetlen munkások aránya az összlétszámban viszonylag alacsony (cca. 10\%). Területi koncentráltságukat illetően, a Vajdaság elmarad a 100 ezer lakóra jutó egységnyi területre kivetített egészségügyi munkás és szakmunkatárs számát illetően az országos szinttől.

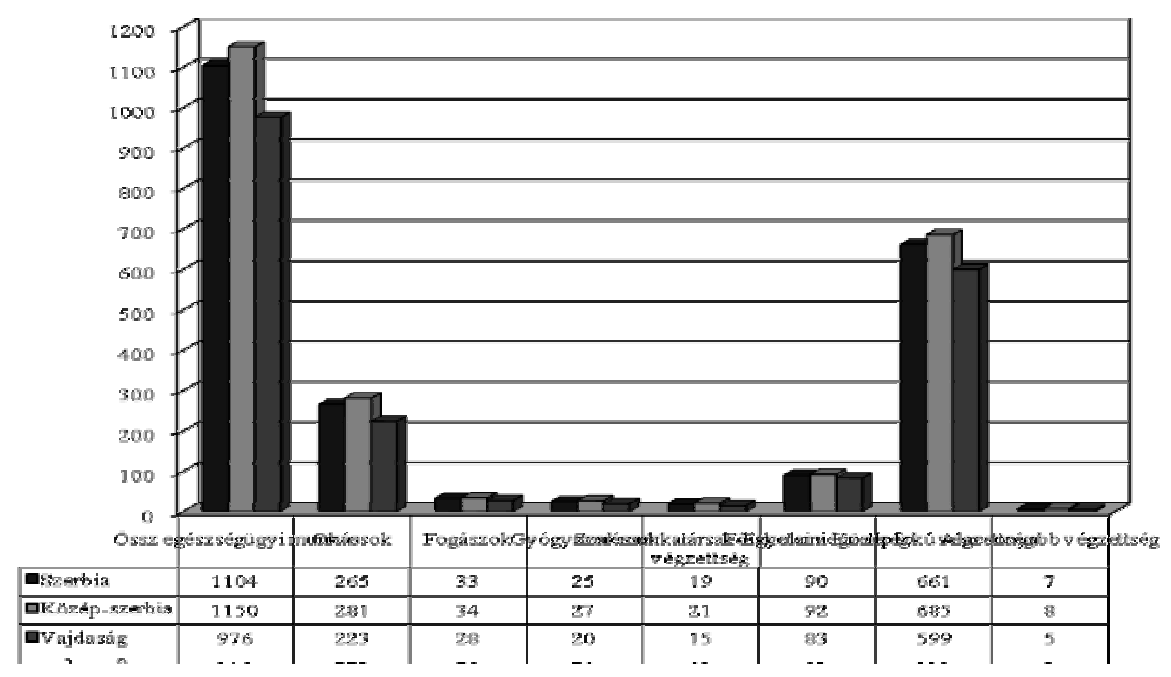

3. ábra: Az egészségügyben dolgozó humánerőforrás területi koncentrációja - 100 ezer lakósra jutó egészségügyi munkás

Forrás: Zdravstveno- statistički godišnjak Republike Srbije 2006.

\section{A munkaerö-hiány:}

- nagy a szakorvos-hiány (főleg a kisebb községek esetében). Ez magyarázható szintén a területi marginalizálódás hatásával, de az egyetemi központok rossz területi koncentrációjával is.

- Hiányszakmák: szemész, belgyógyász, nőgyógyász, pszichiáter, röntgenológus, orrfülgégész, gyermekfogász, mentő-szakorvos, gyermekgyógyász, immunológus, tüdőszakorvos,

- Oka az elmúlt 15 év nem megfelelö humánerőforrás politikájára, minisztériumi megszigorításokra vezethető vissza. Várható lesz a szakorvosok további elvándorlása a magasabb juttatások miatt a magánszférába, esetleg külföldre. 
- Külön meg kell említeni a gyógyszerészhiányt, aminek két oka van. Eleve kevés az okleveles gyógyszerész, és inkább magánpatikákban helyezkedne el, vagy nyitnak gyógyszertárat.

- Hiányosság mutatkozik a föiskolai végzettségü szakemberek területén (pl.: főiskolai röntgen technikus). A nyugati gyakorlattal ellentétben, nálunk még mindig nagy a szakadék a közép és felsöfokú végzettségü egészségügyi munkások között. Ennek oka a föiskolai/felsöoktatási szintü egészségügyi képzés hiánya a régióban.

- Az egészségügyi technikusok esetében az általános nővérképzés mellett szakosított, szük-szakképzett káderekre lesz egyre inkább szükség: aneszteziológus, transzfúziós asszisztens, szülésznő, műtős asszisztens, házi-ápolásra szakosodott nővér, geriátriai ápoló, osztályvezető főnővér, stb.

- Hiányszakmaként kezelik a gépkocsivezetőket is. (B, C, D kategóriákkal).

- A többi, időszakonként megjelenő hiányt az intézmények gyorsan megoldják a munkaerö-piaci „spontán” kínálattal.

Az egészségügyi intézmények tevékenységének „racionalizálásával” a specialista szolgáltatások számát csökkentették legradikálisabban, valamint a stacionár jellegü betegellátást (már évekkel korábban) - így sok község csak egészségházat müködtet. A törvény előlátja sürgösségi csapatok verbuválását, amelyhez szükség mutatkozik felkészült, speciális tudással rendelkező egészségügyi munkások: gépkocsivezetö, sürgősségi növér asszisztens, mentős szakorvos.

A foglalkoztatottakkal szembeni szakmai követelések-kompetenciák:

- szerb és magyar nyelvtudás mellett más nyelvek ismerete,

- a számítógép-használat (már az egészségügyi munkások körében is).

- Minden munkással szembeni követelés a lojalitás, szakmai alázat, szakmai érdekeltség, flexibilitás, kreativitás, kommunikációs készség, szervezői készség, $s t b$.

- Hajlandóság a továbbképzésre, a szakmai tudás fejlesztése, új eljárások, módszerek elsajátítására, tehát egy flexibilis, rugalmas magatartás tanúsítása a munkavállalók esetében.

- „Legyen a munkavállaló tapasztalt, nyitott, széles látókörü, rugalmas, ügyes, mindent tudjon, amit a szakma megkövetel. Korhatár, nemi megkülönböztetés 
nincs. Szakmai érdekeltség, alázat és türelem, valamint a kommunikáció - ezek a legfontosabb elvárások”- egy magánpraxis vezetőjének véleménye szerint.

- A munkáltatók véleménye szerint a piacképes képzés által delegált, könnyen értékesíthető kompetenciák: Gyakorlatorientált, rugalmas, sok - a közvetlenül eladható tudásra épülö készség/ tudás, (ez nálunk hiányos, belső tréning ${ }^{4}$ ), szakosodás, speciális- piaci igényekhez idomított szakok.

A pillanatnyi munkaerőfeleslegek az állami intézményekben elsősorban a fogászati szolgáltatás racionalizálása/munkaerő leépítése következtében jelentkeznek. $\boldsymbol{A} \boldsymbol{z}$ egészségügyi intézmények „kötelezö (és egyben maximális) szakmakeresletét” az egészségügyi intézmények szervezésére vonatkozó normatívák definiálják 5 . Az itt meghatározott irányelvek alapján, a vizsgált régió lakosságának viszonylatában feleslegek mutatkoznak a következő kádereknél: laboráns-technikus, fogtechnikus, egészségügyi technikus (nővér), segédszemélyzet (takarítónők), adminisztratív munkások, technikai munkások. Középiskolai végzettségűek között érezhető leginkább a túljelentkezés. Sajnos, pont a feleslegeknek titulált képzettségű kádereknél van túljelentkezés munkavállalási igény szempontjából: legtöbb az egészségügyi technikus, adminisztratív munkás és takarítónő. Szakképesítéssel nem rendelkezőknél is jellemző a túlkínálat. Magas a kiegészítő munkákat folytatók aránya (nyugalmazott, bedolgozó, másodmunkát vállalók). Ez egy megfelelő szakmakínálat esetében nem jelentkezne egyik intézmény szintjén sem.

A jelenlegi alkalmazottak szakképzettsége, tapasztaltsága megfelelőnek mondható. Kisebb eltérések jelentkeznek a munkáltató által elvárt kompetenciák és a végzettségek (iskolai papírforma) között az adminisztrációs munkahelyeken, valamint a fogászati technikusoknál. Itt a legkevésbé kívánatosak a „friss diplomások, érettségizők”, ugyanis a tapasztalat megszerzése ezeken a szakterületeken éveket vesz igénybe, nehezen adaptálhatók az iskolapadokból kikerülők a gyakorlati feladatok ellátásához. A középkáderi

\footnotetext{
${ }^{4}$ Az intézményen belüli tréning, gyakorlati bevezetés szerepe szintén felértékelődik. A fiatal pályakezdők gyakorlati, közvetlen tudásátörökítésre való felkészítése külön odafigyelést követel a humánerőforrás menedzsment részéről, intézményen belül. Ez hiányzik a mi intézményeinkben. Az egészségügyi dolgozók, technikusok új tevékenységi köréről számol be a „Nővérség - Sestrinstvo” folyóirat. Szükségletként fogalmazódott meg az egészségügyi ápoló - edukátor tevékenységi kör intézményesített formája. Ezek az oktató nővérek az iskolai előadókkal karöltve, külön szerepet vállalnak a tanulók gyakorlati felkészítésében. (Az egészségügyi nővérek és technikusok első kongresszusán elfogadott - további standardok és normatívák kidolgozását előrevetítő metodológia). (RADOJEVIĆ, D. et al 2008)

5 Pravilnik o bližim uslovima za obavljanje zdravstvene delatnosti u zdravstvenim ustanovama i drugim oblicima zdravstvene službe = Službeni glasnik RS br. 43./06
} 
ellátottság jó, viszont a föiskolai végzettségü káderekből hiány mutatkozik. A költséghatékony és racionális munkamegosztás elve mentén funkcionáló nyugati humánerőforrás politika az „olcsóbb” házi ápolásra helyezi a hangsúlyt, a drága kórházi bennfekvéses gyógykezelés helyett. Ebben a költség-hatékonyabb rendszerben a föiskolai végzettségü nővér is részt tud vállalni az összetettebb feladatok végzésében, tehermentesítve ez által az orvost, teret biztosítva számára a komplexebb, magasabb szintű betegellátással kapcsolatos feladatok végzésére, így mindenképpen (a munkáltatók egybehangzó véleménye szerint) „Szüksség van egy jó szakembereket kibocsátó, rugalmas és gyakorlatorientált egészségügyi föiskolára az Észak-vajdasági régióban”.

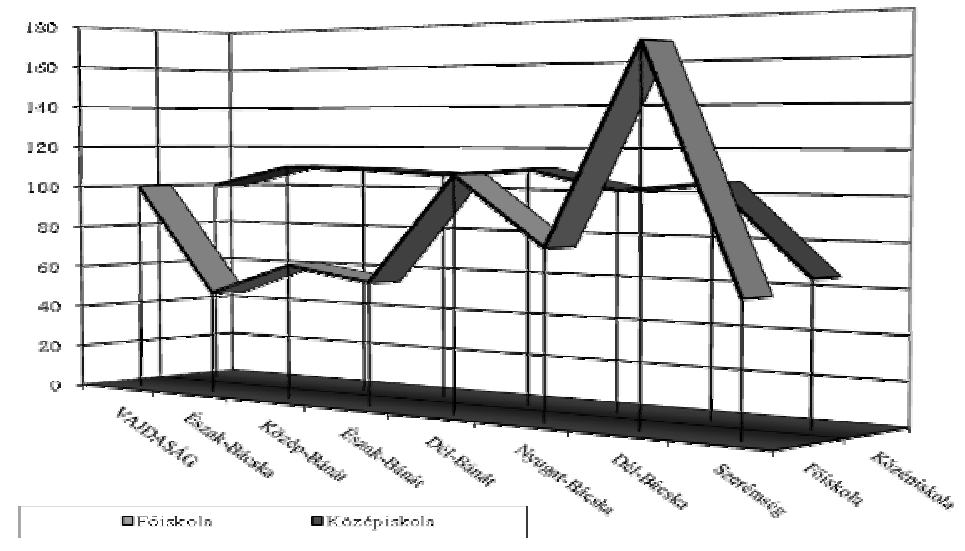

4. Ábra: Eltérések a humánkapacitások kvalitását illetően régión belül Forrás: Zdravstveno- statistički godišnjak Republike Srbije 2006.

Statisztikai adatokra alapozva, szembetűnő főleg az Észak-vajdasági régió hiányossága a humán kapacitásokat illetően az egészségügy és szociális védelem területén. Az interjúalanyok elmondásaival támasztható ugyan csak alá az a tény, hogy az északi régióban, annak ellenére, hogy szükség volna szakosodott föiskolai végzettségü káderekre, nem tud a munkaerö-piaci szakmakínálat ilyen kádereket felvonultatni. Az alkalmazott egészségügyi technikusok esetében, viszont hiányzik a specifikusabb, szakosodott, sokszor felelösségteljesebb munkavégzést megkövetelő további iskolavégzettséget alátámasztó diploma/bizonylat.

\section{A munkáltatók által képviselt felnőttképzési-képzési igények}

Az alkalmazottak betanításában, továbbképzésében, átképzésében valamennyi egészségügyi intézmény aktívan szerepet vállal. Az elmúlt évben az állami egészségügyi 
intézményekben az egészségügyi munkások nagy része részt vett valamilyen továbbképzésen. Ezeket a továbbképzéseket akkreditált - egészségügyi- és más jellegü edukációval foglalkozó intézmények szervezték. A következö képzési formák jelennek meg az intézmények esetében:

- Orvosok szakosítása (állami orvostudományi egyetem keretei között)

- Posztgraduális képzés a menedzsment, illetve a szakorvosok részére (állami egyetemeken)

- Meglévö munkaerö átképzése középiskolai/föiskolai keretek között (adminisztrátorok átképzése gyógyszerész technikussá, röntgen technikusok fötechnikussá, általános egészségügyi technikusok átképzése transzfúziós asszisztenssé, stb.)

- Csökkentett óraszámmal futó (éves) továbbképzés (pl. európai Uniós adminisztrátor-képzés).

- Számítógép-használati tanfolyamok (helyi munkásegyetemek, számítógépekkel foglalkozó cégek szervezésében)

- Kötelezö jellegü, szakmai, pár napos továbbképzések, szakmai-kondíciónáló tréningek (orvosoknak, könyvelöknek, jogászoknak, laboránsoknak, növéreknek, szülésznőknek, gyógyszerészeknek, karbantartónak - biztonságfelelösnek, stb.) az ágazati érdekképviseletek (Szerbia Egészségügyi Intézményeinek Kamarája, Szerb Orvostársaság, Számvevöszövetség), illetve a szakszervezetek szervezésében.

- Gyakornokok vizsgáztatása a Közegészségügyi Intézetekben (Zavod za javno zdravlje) Szabadkán és Nagykikindán)

- Gyógyszerforgalmazók szponzorálása alatt futó oktatási jellegű előadások, gyógyszerbemutatók, demonstrációk, stb.

- Belső tréningek (tűzvédelmi, müszerhasználati, stb.) a kollektíva tagjainak vezetésével.

- Meghívott elöadók/orvosok/kiemelkedö szaktekintélyek intézményen belüli, nem formális elöadásai

- A folyamatos továbbképzéseken - pontgyüjtő előadássorozatokon történő részvétel (a Kamara kezdeményezésével).

„a jövőben szervezendö elöadások minden témában mondhatnának újat az egészségügyi dolgozóknak: „az általános orvosoknak hasznos, alkalmazható, 
mindennapi dolgokról kell, hogy szóljanak ezek az elöadások, másrészt helyet kellene adni az újdonságoknak is a szükebb specializált ágakban (pl. endoszkópos szinusz-operáció az orr-fülgégészetben, lézeres szemmütét a szemészetben) Fontos, hogy szakorvosok, jó szakemberek adjanak elö, és a fontos problémákról beszéljenek.” Egyik interjúalany elmondásai szerint.

Célszerü és mérvadó véleményt mutat egy másik interjú tartalma: „Olyan mindennapi témákat tartok még fontosnak, amelyekben akár a közös tapasztalatcsere is sokat segíthet kollégák között. Például: a belgyógyászat minden területe, újraélesztési kurzus, szemészet, ginekológia, neuropszichiátria (agyvérzés, trombózis felismerése nem egyértelmü esetekben), pszichológus - pszichiáter segítsége a függőségi betegségek kezdeti kezelésében (pl. tanácsadás, hogy tudjon egy beteg a cigarettáról lemondani otthoni körülmények között, terápia nélkül), stb...."

A nem megfelelö munkaképességgel rendelkezö alkalmazottak számára az intézmények hajlandóak a továbbképzéseket/átképzéseket/szakositásokat finanszírozni. A munkáltatók számára ideális volna az egészségügyi intézmény területén megszervezett, tömeges, csoportos folyamatos edukáció. Az ilyen jellegü elöadások által lehetőség nyílna a foglalkoztatottak számára elöirt licenc megszerzéséhez szükséges pontok begyüjtésére is (164 pont - 7 éves periódus orvosok esetében).

\section{A régió oktatási intézményeinek felnőttoktatási felkészültsége - esettanulmányok}

A kutatási projekt egyik alapvető célja volt minősíteni a régió felnőttoktatási, felnőttképzési kapacitásait. Az észak-Bácskai régió oktatási intézményeiben készült esettanulmányok, iskolaigazgatói mélyinterjúk elemzésével lehetőség nyílt a teljes ágazatra vonatkozó empirikus kutatási eredmények megfogalmazására.

Az egészségügyi szakmunkás képzés középfokon a régióban már 1948-ban megkezdődött. A régió egészségügyi káder-képzésében tradicionálisan két intézmény osztozik, ezek a zentai és a szabadkai egészségügyi középiskolák. Fokozatosan alakult ki mindkét intézmény esetében a véglegesnek tekinthető intézményi jogállás. A helyi vezetés mellett sokszor más tényezők (lokáció, intézményi infrastruktúra, stb.) is hátráltatták az intézmények zökkenőmentes történeti-fejlődési pályáját. Az alapítói jogok átruházásával 2003-ban a Vajdaság Autonóm Tartomány definiálja véglegesen az iskolák jelenlegi jogállását. Eleinte három éves képzés müködött (ún. orvossegéd, illetve ápolónő-képzés), majd a '80-as évek folyamán két éves képzés formájában is folyt az oktatás, míg 1986-tól a 
képzés négy éves oktatási profilok keretei között bonyolódik. Mindkét intézmény intenzív háttértámogatásban részesül a helybéli egészségügyi és szociális védelem területén tevékenykedő intézmények személyében, hozzájárulva a gyakorlatorientált képzés megszervezéséhez. Szabadkán jelenleg 19 tagozat, Zentán pedig 13 tagozat müködik, jelentős magántanulói kontingenssel. A regionális munkamegosztást illetően - a zentai egészségügyi iskola biztosítja Bácska és Bánát minden településéről/szórványból érkező tanuló magyar és szerb nyelven történő szakképzését, míg a szabadkai intézmény régióközponti funkciókat lát el az Észak-Bácskai régióban, illetve a tömb egészségügyi szakmunkás-produkcióban. Mindkét iskola népszerünek számít a tanulók körében. Felsőoktatási intézmény (egészségügyi tudományágat képviselő) nem működik a régióban.

A '90-es évek végén, illetve 2000 után kezdődött meg az egészségügyben az új oktatási profilok folyamatos bövítése. Mindkét iskola piacképes szakokat müködtet, külön figyelmet szentelve az aktuális piaci igényeknek, a felnőttképzés szellemében megfogalmazódott átképzéseknek, kurzusoknak, szakosításoknak. Folyamatos és konzisztens oktatási politikával és az intézmény rugalmasságának köszönhetően létrejött egy színes kínálattal, fejlett kapacitásokkal rendelkezö többnyire egészségügyi képzést folytató, újító szellemü iskola Szabadkán, valamint egy tradicionális, konvencionális viselkedési formát követő, minőségbiztosítási szabványokkal rendelkezö iskola Zentán.

Az egészségügyi iskolákban müködő oktatási profilok:

Egészségügy és szociális védelem területén:

- általános - egészségügyi nővér-technikus (Zenta, Szabadka), nevelőnők (Szabadka)

- szakosított egészségügyi középfokú képzés: fizikoterápiás technikus, szülésznő (Zenta, Szabadka)

- egészségügyi szakmunkatársak (gyógyszerész-technikus, laboráns technikus Zenta, Szabadka)

- fogászati-technikus, fogászati asszisztens (Szabadka)

- esetenkénti átképzés, kiegészítő képzés, továbbképzés - specializáció

Személyi szolgáltatások:

- $\quad$ kozmetikus technikus oktatási profil

- $\quad$ személyi szolgáltatások területe - férfi és női fodrász, manikürös, pedikürös

- esetenkénti átképzés, kiegészítő képzés, továbbképzés - specializáció 
A zentai középiskola oktatásgyakorlatában az átképzések honosodtak meg inkább (pl.: egészségügyi technikus átképzése fizikoterápiás technikussá), míg a szabadkai iskola az átképzések mellett egyre inkább a szakosításokra helyezi a hangsúlyt (pl.: röntgen asszisztens, transzfúzionista). Szem előtt tartva a tudás minőségének rendkívülien gyors elévülését, a szabadkai középiskolában megfogalmazódott egy felnőttképzési koncepció: „térképalapú képzési rendszert - azaz a moduláris oktatás”. Ezzel a fajta oktatási koncepcióval válik lehetövé a munkaerö kompetencia bövítése, a tudáshiányosságok informális oktatáson keresztüli begyüjtése. A rendkívüli tanulók (magántanulók) részére állandó jelleggel nyitva áll az intézmény átképzések és specializációs képzések formájában. Hajlandóság mutatkozna egyéb képzésekre is (A Nemzeti Foglalkoztatás-ügyi Szolgálat kezdeményezésére történt az elmúlt évben a kórházi ápoló (bolničar-negovatelj) átképzési felnőttképzési kurzus is, ahol a kurzust befejező munkanélkülieket sikeresen irányították a gerontológiai intézmények felé, munkát biztosítva a számukra). További tervekmegvalósításra váró projektumok: egy trilaterális (belga, magyarországi és a szabadkai) társulás értelmében, az iskolák közösen vállalkoznak, hogy kidolgozzák a kozmetikus képzés moduláris formáját, egy fejlett, modern felnőttképzés szellemében. Azzal a céllal indult ez a program, hogy közösen kialakítsanak egy olyan moduláris jellegü oktatási programot, amely majd fel tudja készíteni a régió humánerőforrását az említett szolgáltatások lehető legminőségesebb és felelősségteljes nyújtására. Így mondhatni, hogy az iskola bármilyen egyéb felnőttképzési program foganatosítására nyitott.

A tanulói létszámot illetően vannak különbségek a két Észak-Bácskai intézmény között. A szabadkai iskolában a tanulók 10\%-a rendkívüli, azaz magántanuló, akik a felnőttképzés valamely (kevésbé nyilvánosan intézményesített, propagált) formájában: átképzés, szakosítási kurzus részt vesznek az intézmény keretein belül. Zentán a tanulók 16\%-a van magántanulói jogviszonyban. Fontos volna, a képzés ezen fajtáinak nagyközönséggel történő megismertetése, „megszoktatása”, hogy bárki kalkulálni tudjon (tandíj, kapacitások, tannyelv, szakok, óraszám, stb.), és számíthasson a képzés ezen formáira.

A káderhiány, pontosabban a humánerőforrás biztosításának zökkenőmentességét árnyékolja maga az ágazat specifikussága, valamint az ágazatban uralkodó, humánerőforrást érintő igen differenciált materiális viszonyok és jövedelmi struktúra. Az elmúlt években föleg, az egészségügyi ágazatban dolgozók jövedelmi szintjének emelkedése, a magánpraxisok térhódítása (maga az egészségügyi szolgáltatások piaci viszonyokat tükröző 
„megdrágulási folyamata”), nem teszi a jövőben lehetővé az egészségügyi munkások és szakmunkatársak oktatási intézményekben történő teljes idős foglalkoztatását. Ezzel egyidejüleg történik meg lényegében az oktatás, mint ágazat degradációja, amelyből kiutat nagyon nehezen lehet találni. Sajnos, jelen körülmények között lehetetlenség orvost és gyógyszerészt alkalmazni állandó jelleggel, nehezen tudják az iskolák ezt a korlátot áthidalni. A humáneröforrás összetétele, ennek ellenére jónak mondható, a tanári kar egyetemi és föiskolai végzettségének arány 80 a 20-hoz.

Sokszor problémát jelent a kis (esetleg nem kompetens, illetve indifferens) gárdával tevékenykedő iskola esetében a kezdeményezések, pályázati lehetőségek, projektkivitelezések megvalósítása, és ezek a feladatok az igazgató személyét terhelik. Hiányzik a kompetens iskolamenedzselési funkciók, oktatásgazdálkodási mechanizmusok megalapozottsága. Az iskolák nincsen teljes mértékben tisztában azzal a jövedelemforrással, amelyet számukra a felnőttképzés rendezett körülmények között történő beindítása hozhatna.

\section{ZÁRADÉKOK}

A kutatás három pontba sorolt hipotézisének elemzése:

- A központi hatalom által behatárolt jogi, pénzügyi és hatásköri korlátok miatt a regionális együttmúködés oktatásügy - egészségügy - foglalkoztatás ügy között nem tud intézményesülni. Regionális-lokális igény van, regionális-lokális intézményrendszer azonban nehezen tud kialakulni. Szinte minden területet lefedő teljes vertikumot képviselő jogforrási skála épült az egészségügy és szociális védelemre az elmúlt 2-3 évben. Az állami szektorban müködő egészségügyi intézmények erőteljes racionalizációs folyamatokon mennek keresztuil, amely legkifejezettebben az egészségügyi védelem megszervezésére szánt pénzeszközök csökkentésében nyilvánul meg. Mivel az egészségügyi szolgáltatások pénzelését elsősorban, a szolgáltatást nyújtó humánerőforrás direkt és indirekt költsége határozza meg, az új törvények értelmében, pedig ezek igen decid kádernormatívák alkalmazását követelik meg - az intézmények a racionalizációs folyamatokat menedzselve nem tudnak/és nehezen hajlanak újabb, képzettebb káderek alkalmazására (a nem kompetensek helyett). Általánosítható a létszámleépítés, míg a meglévő, nem megfelelö kompetenciákkal rendelkezők esetében az átképzés. 
- Az elvárásoknak sem az oktatási intézmények által képviselt programok (rendes oktatás és rendkívüli oktatás-felnőttképzés), sem az útnak engedett érettségizők nem felelnek meg, szaktudásuk nem elég speciális, gyakorlatias. Ez leginkább a középfokú végzettséggel rendelkezőket, alacsonyabb kvalifikációval rendelkezőket érinti a leginkább. Sajnos, az iskolákból frissen kikerülő érettségizőket - új munkaerőt a munkaerőpiac nagyon kis mértékben tudja csak alkalmazni. Hosszú a várakozási idő, és gyakran csak átképzések árán tudnak a potenciális munkavállalók is a szakmakeresletnek megfelelni. Az átképzések viszont eleve dupla pénzek - halmozott kiadások/erőfeszítések munkavállaló, állam, szülő, stb. részéről. Általában az általános képzések azok, amelyekből később a speciális szükségletek miatt átképzéseket indítványoznak.

- Nincs érdekegyeztetés a lokális akterek között, ezzel beigazolódott a harmadik pontban megfogalmazott felvetés. Megfelelö - konzisztens, többoldalú dialógusra (munkáltató, iskola, munka-ügyi hivatal, egyén) épülö képzési politika, lokális érdekeket, szükségleteket követö módon, hatásköri (tartományi és lokális) kompetenciák érvényesítésével tudná csak ezt a problémát megoldani. Sok esetben nem is a hatáskörök hiánya okozza a tehetetlenségeket, hanem ezen párbeszéd érdektelensége, az alulról induló törekvések kifejezésre juttatása. Jelenleg passzivitás tapasztalható, továbbá az esetleges dialógus is megoszlik: az iskolák és egészségügyi intézmények külön, valamint az iskolák és a foglalkoztatás-ügyi szolgálatok szintén külön „tárgyalgatnak”. Hiányzik a munkaeröpiacon lévö szakmabeli munkanélküliek átképzésének közös terve, konkrét programokkal. Nincs konzisztens, egyszerüen (az érdekeltek felé publikált), követhetö felnöttképzési terve (átképzés, továbbképzés, kiegészítö képzés, szakosodás) a középiskoláknak. Ad hoc müködik a felnőttképzés. Ha felkeresik/felkérik őket, vesznek fel magántanulót. A hangsúly még mindig érezhetően a rendes tanulói viszonyra épülő (15-19 éves generáció) kapacitásokon van. Kapacitásfeltöltő viselkedési magatartás érvényesül. Szakot az iskolák sokszor az érdeklődés alapján nyitnak. Hiányos a munkamegosztás e téren a régió középiskolái között. A szakok másolódnak, kapacitások gyakran üresen maradnak. 


\section{JAVASLATOK}

Nélkülözhetetlen egy egységes - szolgálatkész, flexibilis és mobil egészségügyi felnőttoktatási háló müködtetése. A felnőttoktatás tervezésében tartományi hatáskörök érvényesítésének kell helyet adni. A felnőttoktatás modalitásait az egészségügy esetében az oktatási intézmények következő programkínálatával lehet biztosítani:

- átképzések - az ágazati racionalizáció miatt.

- kiegészitő képzések - lehetőséget biztosítani a munkanélküli (nem kompetens, vagy a meglévő végzettséggel szemben indifferens, váltani akaró fiatal és idős munkát aktívan keresők) munkaerő-piaci kondícióinak feljavításához.

- Moduláris jellegü képzési programok akkreditálása az oktatási intézmények részéről, amelyek során lehetőség nyílik a kompetencia-hiányosságok kiküszöbölésére, bizonyos kiegészítő tudás/képességek megszerzésére.

- Folyamatos továbbképzések szervezése az egészségügyi dolgozók - technikusok számára, munkavégzésük feltételeinek biztosításához.

- Helyi jellegü szemináriumok, oktatási rendezvények szervezése.

- A föiskolai végzettségü speciális szaktudással, gyakorlati tudással rendelkezö humánerőforrás iránti megnövekedett igény miatt a régiónak alapítani kell egy egészségügyi föiskolát, több szakkal, gyakorlatorientált képzéssel, hogy pótolni tudja az évtizedek óta jelentkező humán kapacitásbeli hiányosságokat. Az egyes hiányszakok gyakorlatorientált, felső szintü oktatása megvalósulhat interregionális, határon átívelő főiskolai karok együttmüködésével is.

- A hangsúly a középfokú oktatáson van továbbra is, amely egy kiforrott, tradicionális közoktatási hálóra épül. Ez a háló olyan specializált tudásátörökítést kell, hogy meghonosítson a régióban, amely túlnövi magát az eddigi konvencionális középiskolai oktatáson. Fontos a munkáltató által megfogalmazott specializált és gyakorlatorientált képzés megteremtése. A régiónak erre van szüksége.

\section{IRODALOM}

Institut za Javno zdravlje Srbije „Dr Milan Jovanović Batut“ 2007: Zdravstveno- statistički godišnjak Republike Srbije 2006. Elit Medica, Beograd. pp. 61-100.

KINCSES GY. 2000: Az egészségügy új szemlélete = Egészségügyi Menedzser 5. sz. http://www.vitalitas.hu/olvasosarok/online/eumen/2000/5/szeml.htm 
Komora zdravstvenih ustanova Srbije 2007: Bilten Informacija o finansijskom poslovanju zdravstvenih ustanova Srbije za period I-XII 2006. godine -Bilten. 8. évf. 3. sz. pp.43-52.

MILOSAVLJEVIĆ, T.: Health system in the Republic of Serbia. Ministry of Health. Republic of Serbia,

2005. 9. p.

http://www.pallcare.belgrade2005.org.yu/cd/1Health\%20system\%20in\%20the\%20R epublic\%20of\%20Serbia.pps (2008. 12. 01.)

Ministarstvo zdravlja Republike Srbije 2001: Vizija sistema zdravstvene zaštite u Srbiji. Beograd, Ministarstvo zdravlja. 17-149.p.

Ministarstvo zdravlja Republike Srbije 2003: Bolje zdravlje za sve u trećem milenijumu. Beograd, Ministarstvo zdravlja. 1-34.p.

Országos Egészségbiztosítási Pénztár. Biztonság és Partnerség: Feladatok az egészségügyben 2010-ig. http://www.oep.hu (2009.01.30.)

Pravilnik o bližim uslovima za obavljanje zdravstvene delatnosti u zdravstvenim ustanovama i drugim oblicima zdravstvene službe = Službeni Glasnik RS br. 43./06

Pravilnik o uslovima, kriterijumima i merilima za zaključivanje ugovora sa davaocima zdravstvenih usluga i za utvrđivanje naknade za njihov rad za 2008. godinu = Službeni Glasnik RS br. 127/07

RADOJEVIĆ, D. et al. 2008: Prikaz delokruga rada VMS - Zdravstvenog vaspitača edukatora. Sestrinstvo 5. évf. 14. sz. pp. 24-26.

TAKÁCS Z. 2008: Egészségügy, egészségügyi szakoktatás.-In: GÁBRITY MOLNÁR I. (szerk.): Képzetteké a jövő. A felnőttképzés háttere Észak-Bácska iskolahálózatában. Regionális Tudományi Társaság, Szabadka. pp. 129-139., pp. 189-196.

Uredba o Planu mreže zdravstvenih ustanova = Službeni Glasnik RS br. 42/06

Zakon o zdravstvenoj zaštiti = Službeni Glasnik RS br. 107/05

Zakon o komorama zdravstvenih radnika = Službeni Glasnik RS br. 107/05 
Prošireni izvod članka

(Serb extended abstract)

\title{
REGIONAL REQUIREMENTS OF THE MEDICAL EDUCATION, MEDICAL ADULT EDUCATION'S PRESENT AND FUTURE IN THE NORTH VOJVODINA REGION
}

\section{REGIONÁLIS IGÉNYEKET SZOLGÁLÓ EGÉSZSÉGÜGYI SZAKOKTATÁS, FELNŐTTKÉPZÉS JELENE, JÖVÖJE AZ ÉSZAK- VAJDASÁGI RÉGIÓBAN}

\author{
Takács Zoltán, okl. közgazdász \\ Pécsi Regionális Politika és Gazdaságtan Doktori Iskola, \\ Regionális Tudományi Társaság Szabadka. \\ Cím: $\quad 24420$ Magyarkanizsa, Sumádia utca 31. \\ Tel: $\quad$ 063-16-19-118 \\ $062-27-28-45$ \\ E-mail: $\quad \underline{\text { takacszoli@stcable.rs }}$
}

Nakon par godina od započetka reformi u zdravstvu, polako se sve izrazitije suzbija „sloboda kretanja“ indirektinih korisnika budžeta. U protekle 2-3 godine je donet niz pravnih akata sa kojima je regulisana oblast zdravstvene zaštite i socijalnog osiguranja. Zdravstvene ustanove u državnom sektoru prolaze kroz proces snažne racionalizacije, što se najviše odražava na smanjenju namenskih sredstava za organizovanje zdravstvene zaštite. S obzirom da finansiranje organizovanja zdravstvene zaštite prvenstveno zavisi od direktnih i indirektnih troškova ljudskih resursa u procesu pružanja zdravstvenih usluga, a s druge strane i novi pravni akti nameću decidne kadrovske normative na zdravstvene ustanove. Zdravstvene ustanove preopterećene racionalizacijom, jednostavno nisu u mogućnosti za adekvatno animiranje i odabir kadrova po njihovoj kompetetnosti. U ovakvim okolnostima je uobičajeno otpuštanje radnika koji predstavljaju višak po normativima Ministarstva zdravlja, ili prekvalifikacija zaposlenih sa neadekvatnom stručnom spremom, i kompetencijama. 
Ovom procesu su najviše izloženi oni sa srednjom i nižom stručnom spremom. Nova radna snaga - maturanti srednjih škola se teško zapošljavaju, dugo je prosečno vreme do prvog zaposlenja, do kojeg se najčešće dolazi samo putem prekvalifikacije, dodatnih edukacija. Jedino je tako moguće dostići poželjni nivo kompetencija u skladu sa zahtevima tržišta rada, odnosno poslodavaca. Dodadatne edukacije psihički, fizički a pre svega finansijski opterećuju poslodavce, državu, roditelje, pojedinca. Najčešće se konvertuju obrazovni profili opšteg usmerenja u neke specifične, specijalizovane obrazovne profile, putem prekvalifikacija. Pronalaženje rešenja za ove probleme ni malo nije lako. Potrebna je inicijativa za pokretanje dijaloga u obrazovnoj politici, između poslodavaca, škola, zavoda za zapošljavanje. Neophodne su lokalne (regionalne) ingerencije za prevazilaženje sistemskih problema školstva i tržišta rada. Evidentna je nezainteresovanost, pasivnost i nesposobnost stranaka. Nedostaju kapaciteti za pokretanje inicijativa „odozdo nagore”. Ovaj dijalog momentalno funkcioniše podeljeno: između škole i zdravstvene ustanove, odnosno između škole i zavoda za zapošljavanje, često zbog inicijative resornih ministartava centralističke vlasti. Nema konzistetnog, zajedničkog plana sa konkretnim programima za prekvalifikaciju ili dokvalifikaciju nezaposlenih koji su prijavljeni u zavodima za zapošljavanje na lokalnom nivou.

Srednje škole u regionu Severne Bačke nemaju konzistentan, jednostavan plan obrazovanja odraslih (prekvalifikacija, dokvalifikacija, specijalizacija, usavršavanje), kojim bi trebalo da su upoznate grupe potencijalnih zainteresovanih. Obrazovanje odraslih funkcioniše ad hoc. Ako se poslodavac obrati školi sa zahtevom za dodatnu edukaciju svojih radnika, škole će ih primiti u red vanrednih učenika. Prioritet još uvek imaju kontingenti redovnih učenika (uzrast od 15-19 godina) u srednjim školama, što im predstavlja 90\% ukupnih kapaciteta. Škole se najpre brinu o potrebnom broju učenika za otvaranje određenog obrazovnog profila. Uvođenje novih profila i ponovno otvaranje starih, se bazira na popularnosti istih, između mlade generacije. Manjkava je podela rada između škola u regionu. Smerovi i obrazovni profili se kopiraju, kapaciteti ostaju nepopunjeni ili prazni.

Neophodno je uspostavljenja jedne celishodne, uslužne, fleksibilne mreže obrazovanja odraslih u zdravstvu (kao i u ostalim delatnostima). U modalitete obrazovanja odraslih ubrajaju se:

- prekvalifikacija - zbog procesa racionalizacije u sektoru zdravstva 
- dokvalifikacija - za otvaranje novih mogućnosti za nezaposlene (oni koji aktivno tragaju za novim poslovima, ali nisu kompetetni, osećaju indiferentnost prema postojećoj stručnoj spremi, itd.) i popravljanje njihovih kondicija na tržištu rada u novonastalim okolnostima.

- modularni obrazovni programi - akreditovani od strane obrazovnih institucija, po kojima se pruža mogućnost za prevazilaženje određenih nedostataka kompetencije i za sticanje određenih dodatnih znanja, veština, sposobnosti.

- Kontinuirana edukacija za zdravstvene radnike, medicinske tehničare u regionu, za obezbeđenje uslova za obavljanje njihove delatnosti.

- Seminari, obrazovni simpozijumi oranizovani od strane lokalnih aktera obrazovanja i usavršavanja.

Tendencije ukazuju na potrebe za specijalizovanim, praktičnim obrazovanjem na polju zdravstvene i socijalne zaštite. Ukazuju se posebni zahtevi za angažovanjem ljudskih resursa sa višom stručnom spremom, i sa specijalnim i praktičnim znanjem u regionu. Perspektive uspostavljanja višeg obrazovanja u oblasti zrdavstva su realne. Naglasak je dosada na srednjem stručnom obrazovanju koje se zasniva na uhodanom sistemu tradicionalnog obrazovanja u regionu. Ovaj sistem treba da se prilagodi novim zahtevima tržišta rada, te je neophodno pored konvencionalnog stručnog obrazovanja srednjoškolaca organizovati obrazovanje sa specijalnom ponudom u skladu sa zahtevima poslodavaca. Poslodavci zahtevaju specijalizovano i praktično znanje. Za razvoj regiona na polju zdravstva-obrazovanja-zapošljavanja su neophodni gore navedeni multidimenzionalni uslovi rada i saradnje. 